\title{
INVESTIGATION OF THE SAFETY OF IRON AND COPPER NANOPREPARATIONS ON HUMAN BLOOD PLASMA PROTEINS IN VITRO
}

\author{
Dmytrukha N. M.', Lahutina 0. 5.' , Gromovoy T. Yu.2 , Pylypchuk E. V.3 \\ IState Institution «Kundiiev Institute of Occupational Health of the National Academy \\ of Medical Sciences of Ukraine», Kyiv, Ukraine \\ ${ }^{2}$ Chuiko Institute of Surfase Chemistry of the National Academy of Sciences of Ukraine, Kyiv, \\ Ukraine
}

\section{Stockholm University, Departament of Materials and Environmental Chemistry, Stockholm, Sweden}

Introduction. Today nanotechnological preparations of micronutrients in the form of nanoparticles (NP) and nanoaquachelates $(\mathrm{NACH})$ are used in medicine, veterinary medicine, agriculture, perfumes and food products. Nanoscale causes increased bioavailability and biological activity of trace elements, which can have both positive and negative effects on human health. Thith is due to the special physicochemical properties of the NP, their large surface area and adsorption capacity. It is established that at interaction of nanoparticles with proteins there are disturbances of their structural organization (denaturation). To prevent adverse effects from the use of such nanopreparations, it is necessary to perform toxicological studies of their safety.

The aim of the study was to evaluate the safety of iron and copper nanopreparations (metal nanoparticles and their nanoaquachelates) on the structure of human blood plasma proteins in experiment in vitro.

Materials and methods. The object of the study were aqueous dispersions of nanoparticles of iron and copper (NP Fe $40 \mathrm{~nm}$ and NP Cu $20 \mathrm{~nm}$ ), chemically synthesized and nanoaquachelates (NACH Fe and NACH Cu, particle size $200 \mathrm{~nm}$ ), obtained by erosion-explosive nanotechnology. The study was performed on human plasma proteins (albumin, immunoglobulin G) under conditions of their in vitro exposure to these nanopreparations. Changes in the structure of proteins were evaluated by the optical density of solutions on Mephane spectrophotometer at $405 \mathrm{~nm}$ and the mass spectrs of proteins by MALDI-ToF mass-spectrometry on an Autoflex II (Bruker).

Results. It has been shown that the interaction of NP and NACH of metals leads to changes in the structure and mass of proteins. It was found that the optical density indices of protein solutions changed depending on the concentration of metal NP, their size, and the activity of the base metal. Thus, NP Cu and NACH Cu interacted more actively with albumin, while NP Fe and NACH Fe - with immunoglobulin G (IgG). It was shown that metals in the form of nanoparticels size $<100 \mathrm{~nm}$ caused more intensive structural changes in proteins than their HACH with particles size of $200 \mathrm{~nm}$. Based on the obtained results, safe concentrations of metals NP were calculated: NP Fe $0.06 \mathrm{mg} / \mathrm{ml}, \mathrm{NP} \mathrm{Cu}-0.03 \mathrm{mg} / \mathrm{ml}$, NACH Fe and $\mathrm{NACH} \mathrm{Cu}-0.1 \mathrm{mg} / \mathrm{ml}$.

Conclusions. The NP and NACH of iron and copper incubated with albumin and human IgG in vitro caused structural changes in both proteins and NP. Proteins increased the solubility of NP, which caused the release of metal ions, their attachment to the active groups of proteins, as evidenced by changes in the optical density of solutions and an increase in the mass of proteins. Due to the large surface area, metal NP adsorbed proteins on themselves, causing their aggregation and precipitation. The results obtained make it possible to recommend blood plasma proteins as an in vitro model for the express assessment of the safety and biocompatibility of microelement nanopreparations for human and animal health, as well as during their hygienic regulation.

Key words: iron, copper, nanoparticles, nanoaquachelates, albumin, immunoglobulin G, toxicity, biocompatibility

(C) Collective of authors, 2021 


\section{Introduction}

Trace elements iron and copper are essential nutritional metals that play an important role in functioning of the nervous, endocrine and immune systems of the body. They are involved in almost all vital processes (metabolism, hematopoiesis, growth, reproduction, differentiation and stabilization of cell membranes, tissue respiration). Deficiencies of these trace elements in the body are accompanied by specific structural and functional abnormalities, while their excessive amounts can cause toxic effects [1,2].

Iron and Copper enter the human body with food, as well as with vitamin preparations and dietary supplements in the form of salts (ions) [3]. Modern nanotechnology creates opportunities for the production of new forms of nanopreparations of trace elements, in particular, in the form of nanoparticles (NP) and nanoaquachelates (NACH), where nanoparticles contain molecules of water or biologically compatible carboxylic acids as ligands. Micronutrient nanoparticles are actively used in medicine, veterinary medicine, agriculture, perfumery and food products [4-6].

It is well-known that the mechanism and rate of penetration of metals through various biological barriers depend on the physical and chemical properties of these substances, the chemical composition and the conditions of the internal environment of the body. Metals entering the gastrointestinal tract enter the blood, where they bind with plasma proteins and erythrocyte membranes for their further transport to tissues and organs in a few minutes [7].

It was found that metals in the form of NP can easily penetrate through epithelial cells, spread along the paths of nerve cells, blood and lymphatic vessels. Doing so, they selectively accumulate in different cell types and in certain cellular structures. Having small size, large surface area, charge and high biological activity, metal particles can interact with nucleic acids, proteins, contribute to their unique distribution in organs and tissues, as well as disrupt functions of these biological components [8, 9].

Considering the above, the synthesis and application of nanopreparation of trace elements not only opens up new perspectives, but also creates new risks. The lack of fundamental knowledge of the possible risks to human health necessitates the conduct of appropriate toxicological studies. A detailed study of the behaviour of metal particles in the living organism is now one of the priority tasks of a new direction of preventive toxicology, nanotoxicology [10, 11].

Among the methods of nanotoxicology, much attention is paid to, in vitro models and test systems, alternative experiments on animals [9, 12, 13]. To establish the overall toxicity of chemical compounds, blood plasma proteins are considered as an alternative model [14]. This is because blood proteins perform a number of important functions in the body: transport, protective, and trophic. Proteins also create osmotic pressure and are involved in the maintenance of blood $\mathrm{pH}$, as well as providing protection against blood loss. Proteins belong to the class of natural polymers, for which the relationship between structure and functional properties of macromolecules has been established. Both their amino acid (peptide) sequence and the three-dimensional structure, which is formed in the process of clotting, are extremely important for the functioning of proteins [15].

It has been proved that during the interaction of proteins with heavy metal ions the following changes occur: binding and blocking of protein active centres, their denaturation, with the protein molecule losing its native structure state and necessary properties for functioning in the cell. In addition to disruption of the structure, the interaction of metal NP with proteins can intensify the transport of toxic substances inside the 
cell, disrupt metabolism, unusual accumulation and distribution of NP in the tissues of the body [16].

In our previous studies, the effect of lead ions and lead sulfide nanoparticles (NP PbS) with size of $26-34 \mathrm{~nm}$ and $50-80 \mathrm{~nm}$ on the structure of human albumin and IgG was established. It was shown that lead ions and PbS NP during in vitro incubation with proteins cause their structural and functional changes, the extent of which depended on the metal concentration in incubation solution and particle size [17, 18].

In the study [19], were found, that incubation with proteins to increase the solubility of $\mathrm{ZnO}$, $\mathrm{CdSe}$, iron and aluminum oxides nanoparticles. Metal nanoparticles also influenced protein molecules, causing their aggregation, denaturation and impaired functional activity. Other authors [20] investigated that albumin, when added to the solution of NP PbS, covered their surface and increased their size, as evidenced by the broadening of diffraction reflection bands.

So, in order to prevent the adverse effects of exposure to nanopreparation of trace metals on human health, it is necessary to carry out toxico logical studies on their safety.

The aim of this work was to assess the safety of iron and copper nanopreparations (metal nanoparticles and their nanoaquachelates) in terms of their influence on the structure of human blood plasma proteins in in vitro experiments.

\section{Materials and methods of research}

The nanoparticles of iron (NP Fe) and copper (NP Cu) were synthesized chemically and characterized by physico-chemical properties in the Institute of Biocolloid Chemistry. F. D. Ovcharenko of the National Academy of Sciences of Ukraine [21] and presented for study in the form of aqueous dispersions. The aqueous dispersion of NP Fe was with spherical particles, average size $40 \mathrm{~nm}$, iron concentration $10 \mathrm{mg} / \mathrm{ml}$. The aqueous dispersion of NP Cu was with spherical particles, average size $20 \mathrm{~nm}$, copper concentration $8 \mathrm{mg} / \mathrm{ml}$.

In this work we investigated iron and copper nanoacquachelates (NACH Fe and NACH Cu), which were obtained from chemically pure metal plates using Kaplunenko-Kosinov's method of nanomaterials and nanotechnology [22]. Nanoacquachelates are complexes of metal nanoparticles with carboxylic acid molecules, which increases their bioavailability and biological activity. The nanoacquachelates of both metals were spherical in shape, average size $200 \mathrm{~nm}$, metal concentration in solution was $100 \mathrm{mg} / \mathrm{ml}$.

Among human blood plasma proteins, were selected for experiments those, wich performing transport and protectivefunctions, albumin and immunoglobulin G (IgG) (Sigma, USA).

Spectrometry with the determination of the optical density of solutions was used to determine the effect of metal NP on proteins. Working solutions of NP and NACH metals were prepared in deionized water. Protein solutions were prepared on $0.9 \% \mathrm{NaCl}$ with a final protein concentration of $1 \mathrm{mg} / \mathrm{ml}$. During the experiment, the protein was gently mixed with a $1: 1$ with solution of NP and NACH metals, than incubated for 2 hours at $37^{\circ} \mathrm{C}$. A series of assays were performed for each protein: 1 tube $-1 \mathrm{ml}$ protein $+1 \mathrm{ml}$ $0.9 \% \mathrm{NaCl}$ (negative control); 2 tube $-1 \mathrm{ml}$ protein $+1 \mathrm{ml} 0.1 \mathrm{M} \mathrm{HCl}$ (positive control); $3-8$ tube $-1 \mathrm{ml}$ protein $+1 \mathrm{ml} \mathrm{NP}$ Fe solution (iron concentration: $0.5 ; 0.25 ; 0.125 ; 0.063$; 0.031 and $0.015 \mathrm{mg} / \mathrm{mL}) ; 9-14$ tube $-1 \mathrm{ml}$ protein $+1 \mathrm{ml} \mathrm{NP} \mathrm{Cu} \mathrm{solution} \mathrm{(copper} \mathrm{concen-}$ tration: $0.5 ; 0.25 ; 0.125 ; 0.063 ; 0.031$ and $0.015 \mathrm{mg} / \mathrm{ml}) ; 15-20$ tubes $-1 \mathrm{ml}$ protein + $1 \mathrm{ml}$ NACH Fe solution (iron concentration: 1.0; $0.5,0.25 ; 0.1 ; 0.05 ; 0.025 \mathrm{mg} / \mathrm{ml}) ; 21-26$ tubes $-1 \mathrm{ml}$ protein $+1 \mathrm{ml} \mathrm{NACH}$ Cu solution 
(copper concentration: $1.0 ; 0.5 ; 0.25 ; 0.1 ; 0.05$; $0.025 \mathrm{mg} / \mathrm{ml}$ ). Optical density of research tubes solutions was measured in relation to negative and positive controls on spectrophotometer Mefan (Ukraine) at wavelength $405 \mathrm{~nm}$ [14].

Protein structure disturbance (degree of denaturation) after exposure to nanopreparation of metals was calculated by the formula:

ODTT/ODPC $\cdot 100 \%$, where:

ODTT - optical density of protein solution with nanopreparates (test tubes);

ODPC - optical density of protein solution with $0.1 \mathrm{M} \mathrm{HCl}$ (positive control).

MALDI-ToF mass spectrometry (Matrix Assisted Laser Desorption/Ionization Time of Flight) is one of the modern methods for the investigation of high molecular weight of biological compounds such as proteins, nucleic acids, lipids and oligosaccharides. This method allows investigating protein modifications, fragmentation pathways and the structure of formed covalent and non-covalent complexes. The method is based on matrix-activated laser desorption ionisation with time-of-flight analyser. Protein identification by MALDI-ToF mass spectrometry has driven the development of proteomics and is now used as one of its main tools [23, 24].

For MALDI-ToF mass spectrometry, working solutions of human albumin and IgG (protein concentration $1 \mathrm{mg} / \mathrm{ml}$ ) were diluted with deionised water in the ratio of 1:100. Experimental solutions of metal nanoparticles were prepared by diluting matrix concentrations to $(0.1 ; 0.01$; $0.001 \mathrm{mg} / \mathrm{ml}$ ) in deionized water. Up to $0.1 \mathrm{ml}$ of working protein solution was added to $0.1 \mathrm{ml}$ of $\mathrm{NP}$ or NACH of metal solution (analyte), incubated 2 hours at $37^{\circ} \mathrm{C}$, then mixed with Sinapic Acid (SA) matrix (Fluka) in a ratio of $1: 1$ and applied to a standard steel substrate. After cocrystallization of the matrix with the analyte, the substrate was placed in the working area of the mass spectrometer [24]. Protein mass spectra were measured on an Autoflex II - (Bruker) massspectrometer. Researches were conducted in a range of values from $19000 \mathrm{~m} / \mathrm{z}$ to $300000 \mathrm{~m} / \mathrm{z}$. Total spectra of positive ions were analysed, which were obtained by the accumulation of 600 single spectra. Protein mass spectra were studied at the Muldy Centre of Chuiko Institute of Surfase Chemistry of the National Academy of Sciences of Ukraine.

Statistical processing of obtained results was performed using the methods of variation statistics with the help of statistical analysis program Exell 2007.

\section{Results of research and discussion}

It is now known that during the interaction of heavy metal ions with blood plasma proteins in concentrations higher than physiological, they can bind to the protein sites, which are localized on the surface or in the interdomain space. The interaction of metal ions with the ligands on the surface of the protein causes a decrease in the compactness of the globule packing and its unfolding into the extramolecular space. This increases the ability of hidden protein components in the native molecule to intermolecular interactions with the formation of supramolecular aggregates, thus increasing the optical density of the solution. The incorporation of metal into internal compartments of protein leads to the increase of compactness of protein molecule and corresponding decrease of solution optical density $[15,16]$. Thus, measurement of solution optical density can be used as an indicator of conformational changes in a protein molecule.

According to the results of measurements of optical density of human blood plasma protein solutions after incubation with NP Fe and NP $\mathrm{Cu}$, it was found that these parameters for 
both protein solutions change in direct dependence on concentration of metal NP. The percentage of albumin denaturation was calculated to be $61.7 \%$ for albumin and $86.9 \%$ for Ig $\mathrm{G}$ when exposed to NP Fe in the concentration $(0.5 \mathrm{mg} / \mathrm{ml})$ compared to the positive control; after exposure to NP Cu $(0.5 \mathrm{mg} / \mathrm{ml})$, this index was $180.3 \%$ for albumin and $70.3 \%$ for $\mathrm{Ig} \mathrm{G}$, respectively. A decrease in the exposure dose of metals NP also caused less structural changes in the proteins. The lowest concentration of $\mathrm{NP} F$ e and NP Cu $(0.015 \mathrm{mg} / \mathrm{ml})$ did not significantly affect the structural organization of albumin and $\mathrm{IgG}$, the optical density values of the study samples were close to those of the negative control $($ protein $+0.9 \% \mathrm{NaCl})($ Fig. 1$)$.

Thus, the determined values of the optical density of human albumin and IgG solutions after in vitro exposure to metasl NP allow us to conclude that their effect on plasma proteins depended on the NP size, the concentration and biological activity of the metal. NP Fe were more active to IgG, but NP Cu were more active to albumin. Based on the results of the studies, the concentration of metals NP that did not cause structural changes in the proteins, in particular, for NP Fe $-0.06 \mathrm{mg} / \mathrm{ml}$ and NP Cu $-0.03 \mathrm{mg} /$ $\mathrm{ml}$, which can be safe in the human body.

Measurementof the optical density of protein solutions after in vitro incubation with metals $\mathrm{NACH}$ showed the following results (Fig. 2) The denaturation of albumin after exposure to $\mathrm{NACH}$ $\mathrm{Fe}$ at the highest concentration $(1.0 \mathrm{~g} / \mathrm{ml})$ was $28.5 \%$, and IgG $-66.5 \%$. Percentage of albumin denaturation after exposure to $\mathrm{NACH} \mathrm{Cu}$ at the same concentration $(1.0 \mathrm{~g} / \mathrm{ml})$ was $52.8 \%$, and IgG $-41.9 \%$, respectively. Low concentrations of both metals NACH $(0.1 ; 0.05$ and $0.025 \mathrm{mg} / \mathrm{ml}$ ) did not affect the structural organization of human albumin and IgG in in vitro experiments (Fig. 2).

Thus, for NP Fe and NP Cu, as well as for NACT of this metals, a direct dependence of the optical density indicators on the metal concentration in the incubation solution was established. It is necessary to note, that NACH metals also show selective activity in relation to proteins, namely, NACH Fe was more active to IgG, and $\mathrm{NACH} \mathrm{Cu}$ - to albumin. The data on the

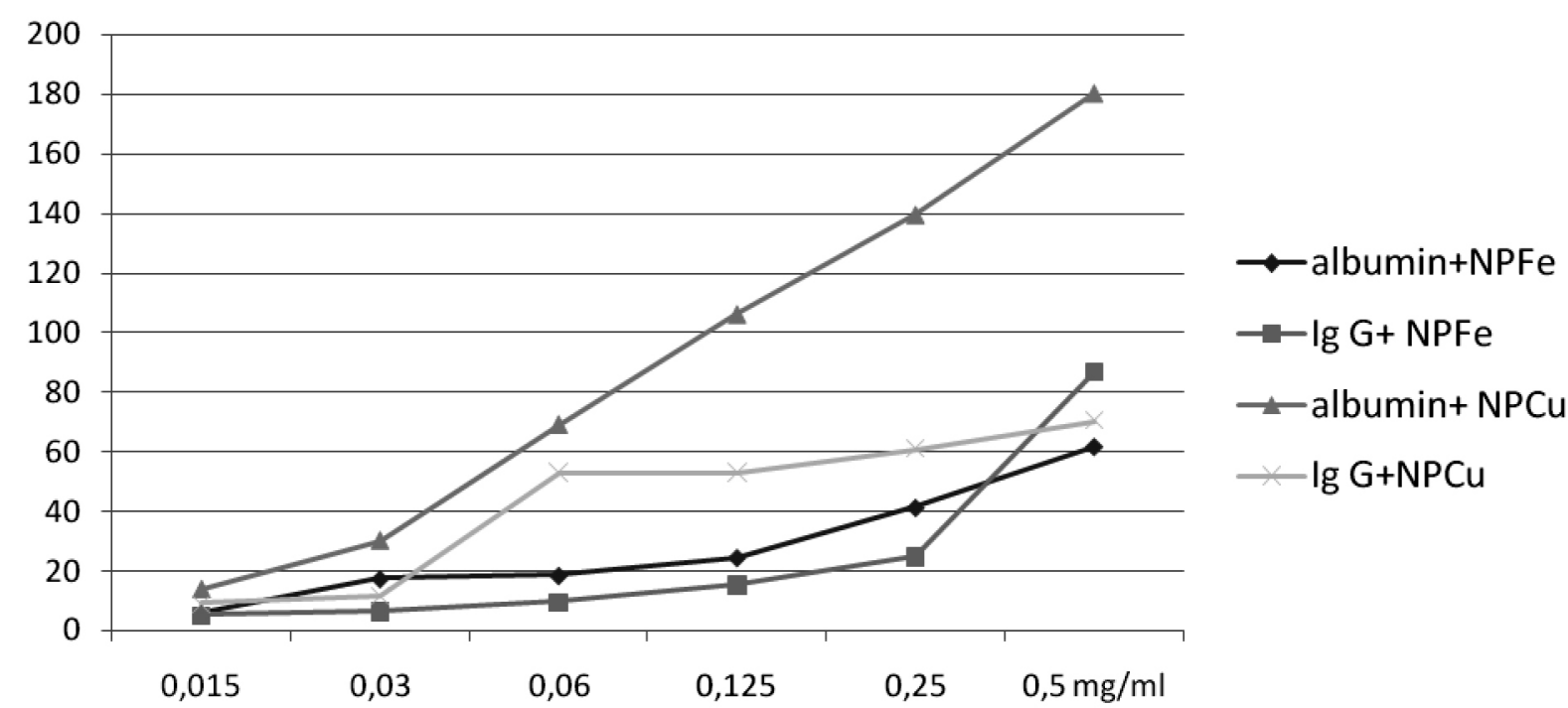

Fig. 1. Degree of denaturation of human plasma proteins (in \% to positive control) after 2 hours of incubation in vitro with solutions of NP Fe and NP Cu at different concentrations of the metals 


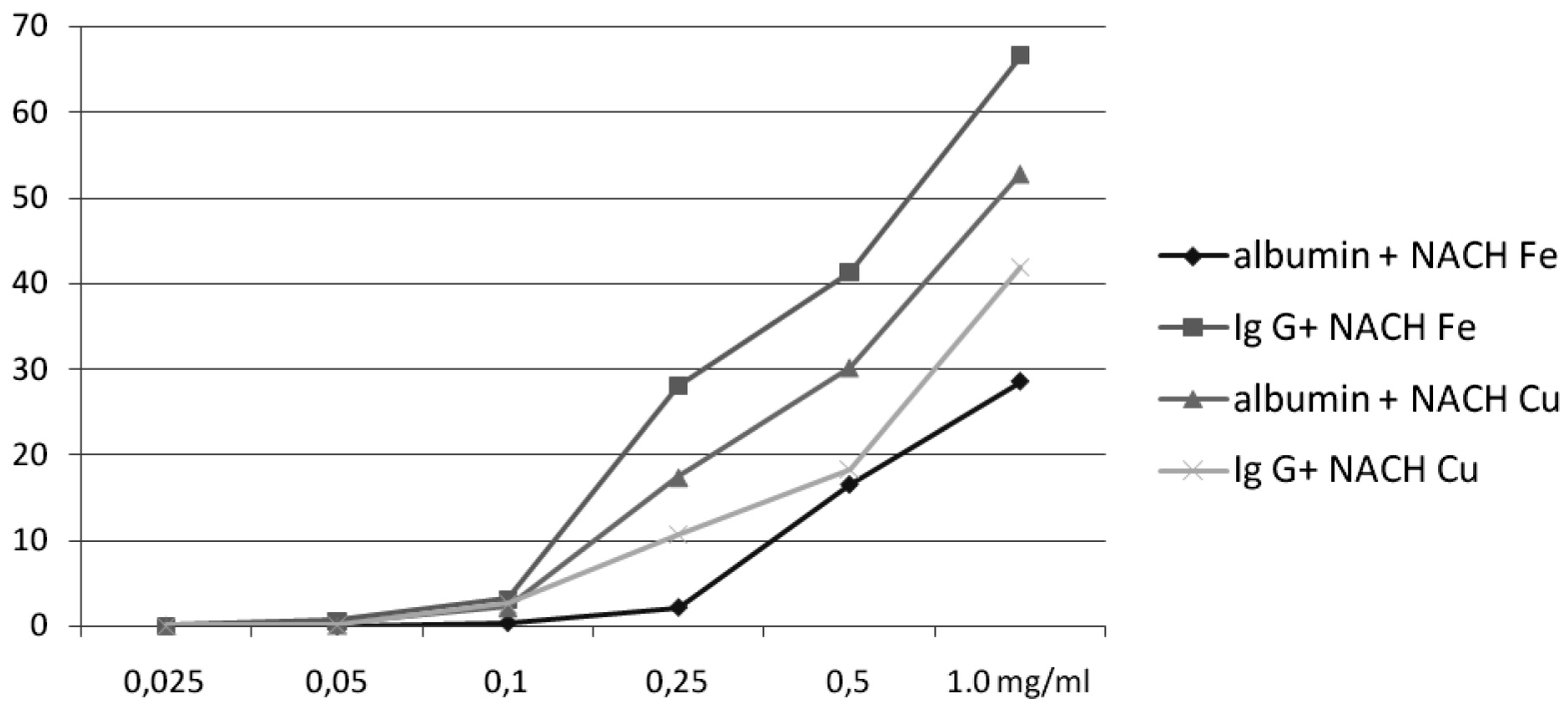

Fig. 2. Degree of denaturation of human plasma proteins (in \% to positive control) after 2 hours of incubation with aqueous solutions of $\mathrm{NACH} \mathrm{Fe}$ and NACH Cu at different concentrations of the metals

optical density of proteins exposed to $\mathrm{NACH}$ of metals made it possible to determine their concentration $-0.1 \mathrm{mg} / \mathrm{ml}$, which had no influence on the structure of both proteins.

Comparison of the optical densities of protein solutions after incubation with $\mathrm{Fe}$ and $\mathrm{Cu}$ nanopreparates leads to the conclusion that $\mathrm{NACH} \mathrm{Fe}$ and $\mathrm{NACH} \mathrm{Cu}$ had less effect on the structure of human blood plasma proteins under in vitro conditions than those metalsnanoparticles. $\mathrm{NACH}$ Fe and NP Fe were more active to IgG, while $\mathrm{NACH} \mathrm{Cu}$ and $\mathrm{NP} \mathrm{Cu}$ showed greater activity agains albumin. The affinity of copper nanopreparates to albumin, and iron nanopreparates agains $\operatorname{IgG}$ can be explained by the fact that, under physiological conditions, copper ions that enter to the blood are primarily bound by albumin and transported further to the liver, whereas iron ions are mainly bound by the $\beta$-globulin protein fraction, take part in the synthesis of immunoglobulins [16].

The next step in the investigation of the effects of NF and $\mathrm{NACH}$ of iron and copper on human plasma proteins was the determination of their mass spectra by MALDI-TOF mass spectrome- try. The measurement of the mass spectra of blood plasma proteins after in vitro incubation with NP and NACH of metals showed that they changed significantly especially after incubation with metals NP (Fig. 3-6).

The peak with the highest mass in the first spectrum corresponded to the mass of the whole IgG molecule and was $148,660 \mathrm{~m} / \mathrm{z}$, corresponding to the molecular ion of the IgG molecule. The peak of $74424 \mathrm{~m} / \mathrm{z}$, corresponds to the connected $\mathrm{H}$ and $\mathrm{L}$ chains of the molecule, the peak of $49600 \mathrm{~m} / \mathrm{z}$ is heavy chain and the peak of $23300 \mathrm{~m} / \mathrm{z}$ is light chain of IgG molecule (Fig. 3). It should be noted that the obtained mass-spectrum of human IgG and its interpretation is in agreement with that of the authors [25].

After incubation of $\operatorname{IgG}$ with NP Fe changes of $\mathrm{m} / \mathrm{z}$ values of corresponding peaks in the massspectrum of positive ions of this protein (Fig. 3, spectrum 2, 3,4) in all concentrations compared to the values in the control (Fig. 3, spectrum 1) were determined.

The calculated increase in mass value of whole IgG molecule after interaction with NP Fe at concentrations $(0.1$ and $0.01 \mathrm{mg} / \mathrm{ml})$ corresponded 
ISSN 2223-6775, Ukrainian Journal of Occupational Health, 2021, 17 (3), 139-150

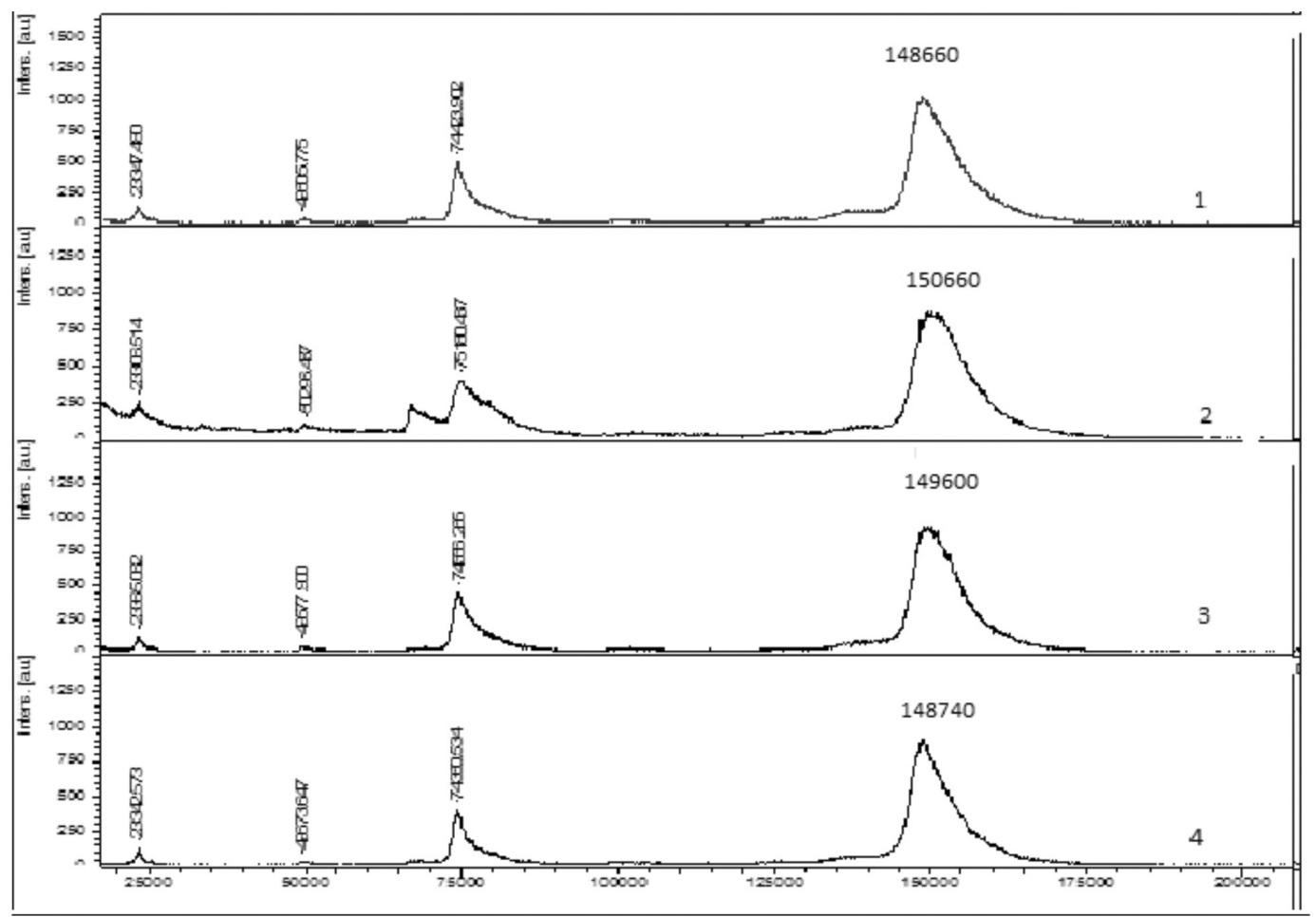

Fig. 3. Mass spectra of immunoglobulin G after incubation with NP Fe: 1 - control;

2 - with $0.1 \mathrm{mg} / \mathrm{ml} \mathrm{NP} \mathrm{Fe} ; 3$ - with $0.01 \mathrm{mg} / \mathrm{ml} \mathrm{NP} \mathrm{Fe} ; 4$ - with $0.001 \mathrm{mg} / \mathrm{ml} \mathrm{NP} \mathrm{Fe}$

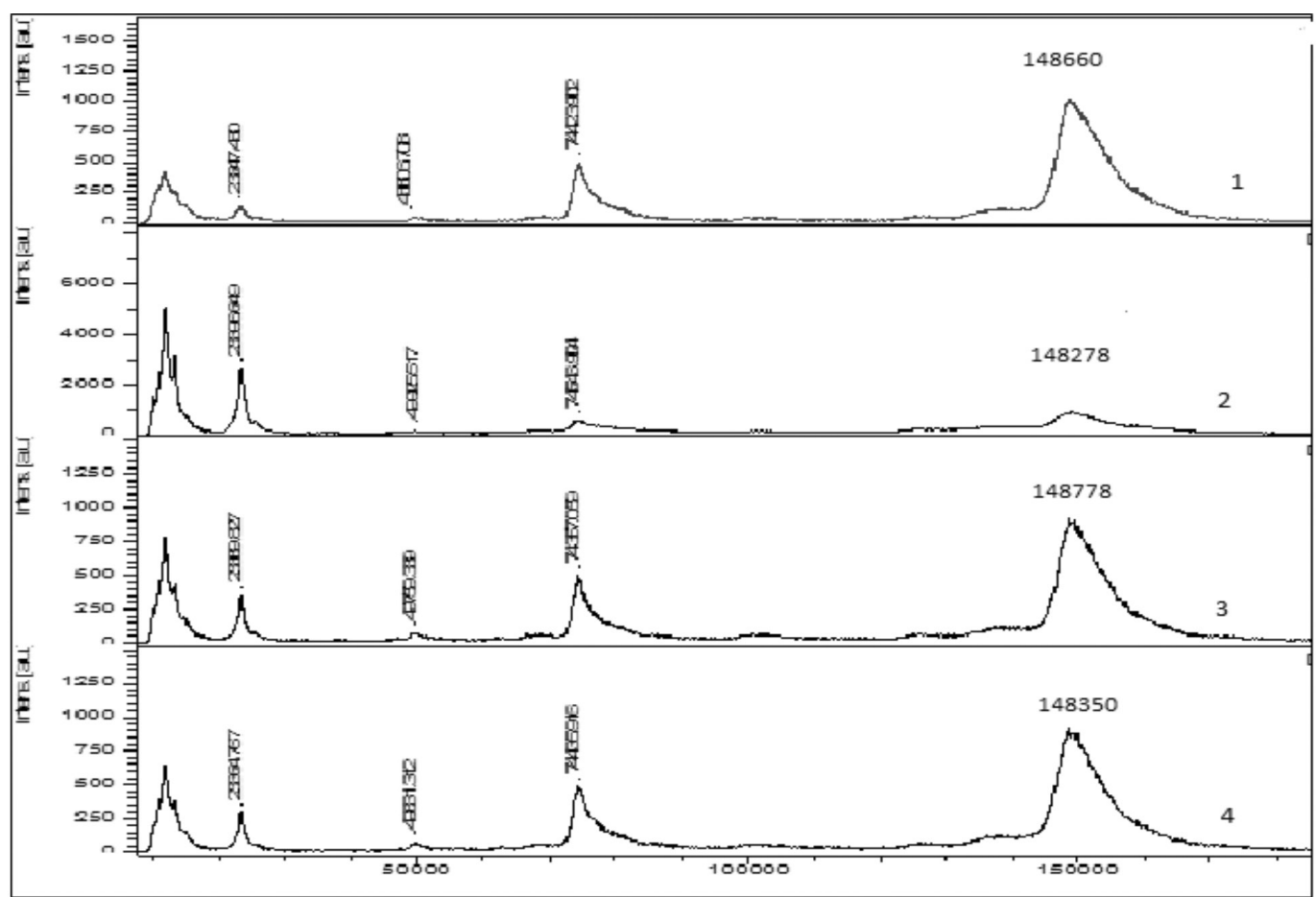

Fig. 4. Mass spectra of immunoglobulin $G$ after incubation with NP Cu: 1 - control;

2 - with $0.1 \mathrm{mg} / \mathrm{ml} \mathrm{NP} \mathrm{Cu} ; 3$ - with $0.01 \mathrm{mg} / \mathrm{ml} \mathrm{NP} \mathrm{Cu} ; 4$ - with $0.001 \mathrm{mg} / \mathrm{ml} \mathrm{NP} \mathrm{Cu}$ 


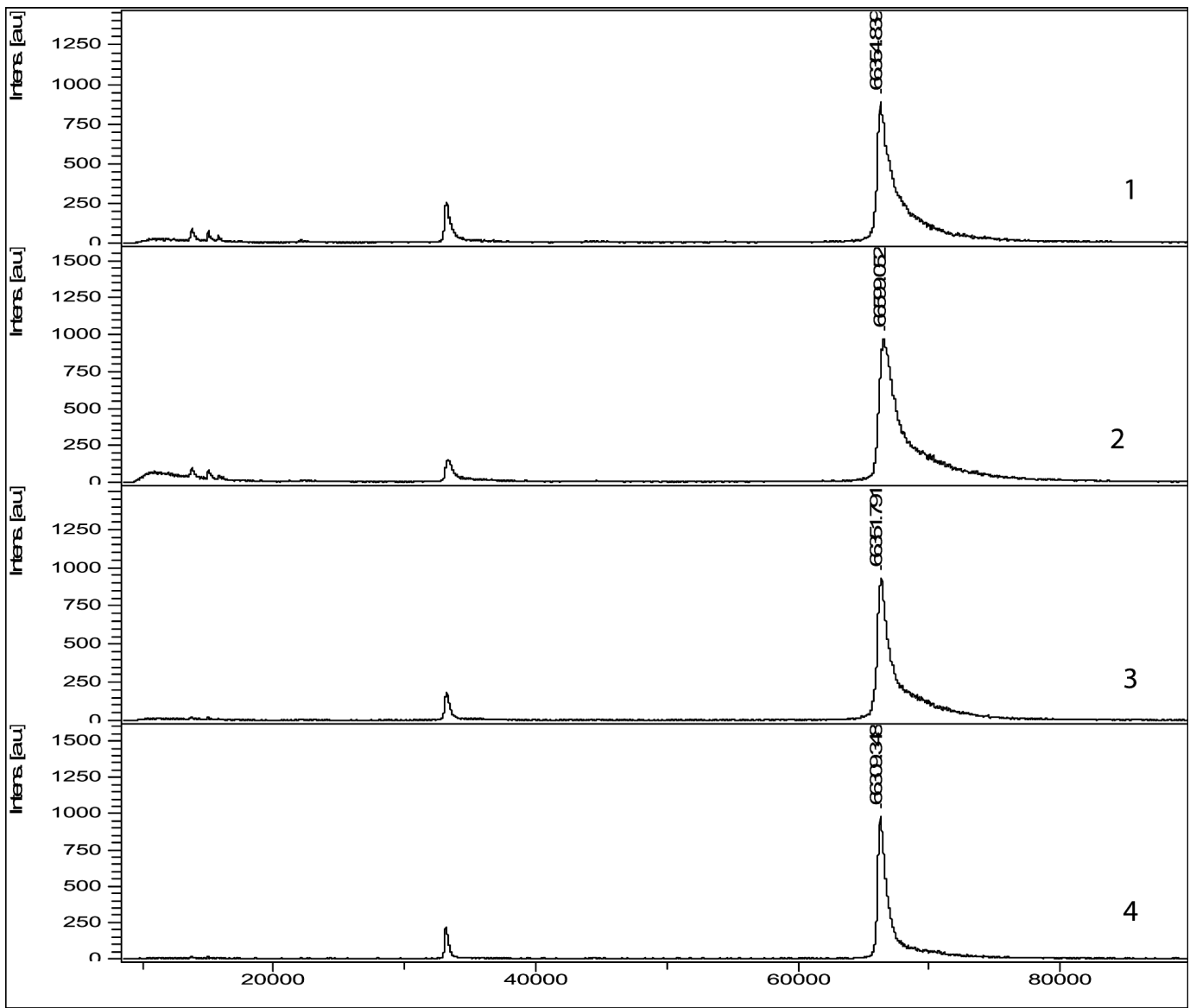

Fig. 5. Mass spectra of albumin after incubation with NP Fe: 1 - control; 2 - with $0.1 \mathrm{mg} / \mathrm{ml} \mathrm{NP} \mathrm{Fe}$; 3 - with $0.01 \mathrm{mg} / \mathrm{ml} \mathrm{NP} \mathrm{Fe} ; 4$ - with $0.001 \mathrm{mg} / \mathrm{ml} \mathrm{NP} \mathrm{Fe}$

to mass values of 35 and $15 \mathrm{Fe}$ atoms, respectively, whereas the mass values of IgG at 0.001 $\mathrm{mg} / \mathrm{ml}$ concentration of NP Fe did not significantly differ from those of control. The latter may be evidence, that NP Fe at a concentration of $0.001 \mathrm{mg} / \mathrm{ml}$ had no effect agains IgG.

The in vitro incubation of human IgG with NP Cu caused slightly different changes in its mass spectrum (Fig. 4).

The addition of $\mathrm{Cu}$ atoms into the whole $\operatorname{IgG}$ molecule occurred at the concentrations of 0.1 and $0.01 \mathrm{mg} / \mathrm{ml}$ (respectively, 10 and 2 atoms), while the 2-nd peak intensity spectrum was weak, which may indicate changes in the structure of this protein, in particular its aggregation and deposition. The most active NP Cu attachment ( 17,15 and 16 atoms) was detected for the
IgG fragment with the mass of about $49000 \mathrm{~m} / \mathrm{z}$ corresponding to the heavy chain. It should be noted that the masses of the light chain of the IgG molecule did not change after incubation with different concentrations of NP Cu.

Thus, the results of measurements of IgG mass spectra suggest that $\mathrm{NP} \mathrm{Fe}$ was most active against the whole IgG molecule, whereas NP Cu was actively attached to its H-heavy chain.

The next protein examined was human albumin. The mass of the whole albumin molecule is 65 to $66 \mathrm{kDa}$. One of the main features of the albumin molecule, which has a transport function, is its ability to bind a large number of different compounds, including metal ions [ 15 , 26]. 


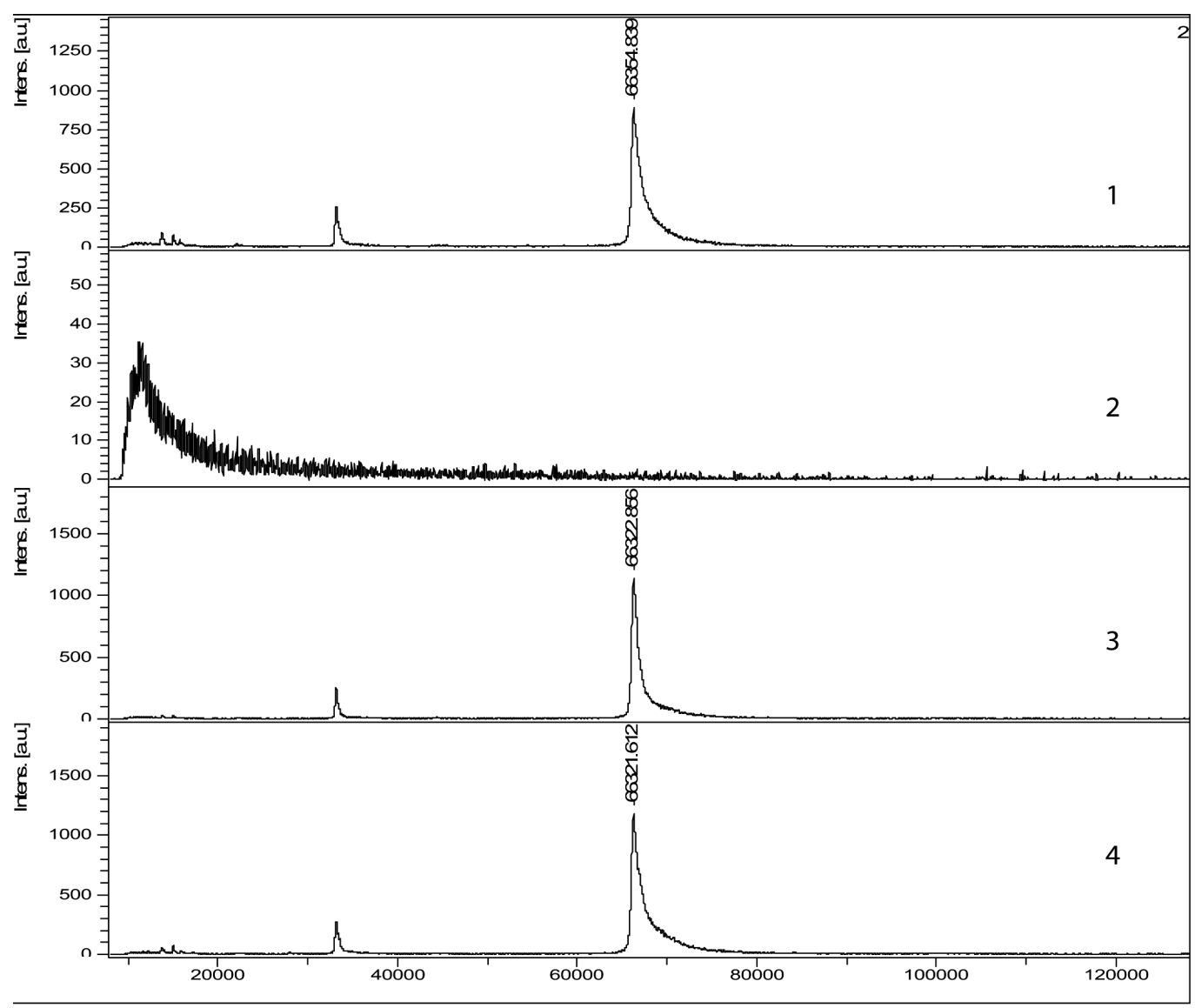

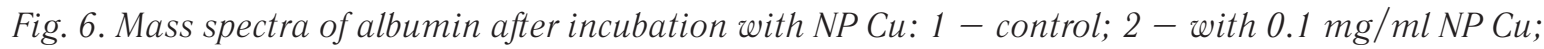
3 - with $0.01 \mathrm{mg} / \mathrm{ml} \mathrm{NP} \mathrm{Cu;} 4$ - with $0.001 \mathrm{mg} / \mathrm{ml} \mathrm{NP} \mathrm{Cu}$

It was determined that the mass of albumin in the control sample was $66355 \mathrm{~m} / \mathrm{z}$ (Fig. 5), which corresponds to the ion of the albumin molecule and does not differ from the values of other authors [25].

The measurement of the mass spectra of albumin after incubation with Fe-particles at a concentration of $0.1 \mathrm{mg} / \mathrm{ml}$ showed an increase in the $\mathrm{m} / \mathrm{z}$ value of the protein molecule compared to control by 245 a.s.m., which corresponds to $4 \mathrm{Fe}$ atoms. The other two Fe concentrations did not change the mass of the albumin (Fig. 5).

Incubation of albumin with NP Cu solution at the highest concentration of $0.1 \mathrm{mg} / \mathrm{ml}$ did not produce a clear mass spectrum (Fig. 6, spectrum $2)$. Low concentrations of NP Cu $(0.01 \mathrm{mg} / \mathrm{ml}$ and $0.001 \mathrm{mg} / \mathrm{ml}$ ) did not significantly affect the albumin structure and did not change the $\mathrm{m} / \mathrm{z}$ value (Fig. 6).

The disappearance of the peak in the low molecular weight zone corresponding to the albumin molecule after incubation with $\mathrm{Cu}$ particles can be explained by its adsorption on the surface of these particles, which contributed to their aggregation and made it impossible to determine the mass spectrum. This assumption is supported by literature data [27, 28], where it is shown that metal particles are capable of adsorbing proteins on their surface, forming a so-called «protein corona».

The results of measuring the mass spectra of albumin and IgG after incubation with the solutions of $\mathrm{NACH} F$ and $\mathrm{NACH} \mathrm{Cu}$ showed that they produced less effect than metal particles in 


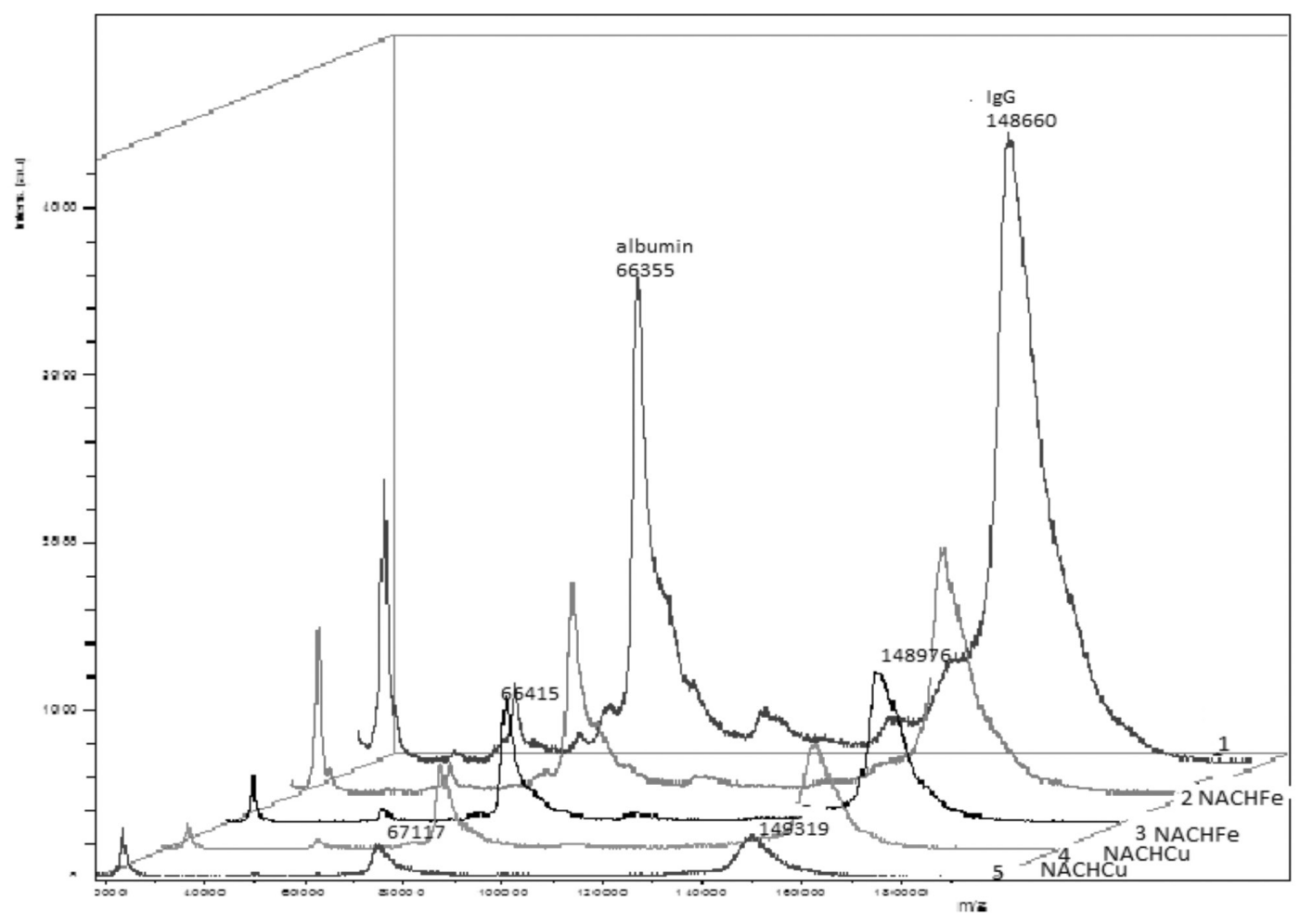

Fig. 7. Mass spectra of albumin and IgG after incubation with NACH Fe and NACH Cu: 1 -control; 2 - NACH Fe $0.01 \mathrm{mg} / \mathrm{ml}$; 3 - NACH Fe $0.1 \mathrm{mg} / \mathrm{ml}$; 4 - NAFH Cu $0.01 \mathrm{mg} / \mathrm{ml} ; 5$ - NACH Cu $0.1 \mathrm{mg} / \mathrm{ml}$

terms of peak intensity and number of attached atoms. Thus, after incubation of IgG with $\mathrm{NACH}$ Fe (iron concentration $0.1 \mathrm{mg} / \mathrm{ml}$ ) the $\mathrm{m} / \mathrm{z}$ value of the molecule increased by 316 a.u.m. ( 6 atoms of $\mathrm{Fe}$ ), and with $\mathrm{NACH} \mathrm{Cu}$ (concentration of $\mathrm{Cu}$ $0.1 \mathrm{mg} / \mathrm{ml}$ ) increased by 655 a.u.m. (10 atoms of $\mathrm{Cu}$ ). Incubation of albumin with $\mathrm{NACH} F$ solution in highest concentration $(0.1 \mathrm{mg} / \mathrm{ml})$ caused the increase of $\mathrm{m} / \mathrm{z}$ value of protein molecule by 60 a.o.m. (1 Fe atom), and with $\mathrm{NACH}$ $\mathrm{Cu}$ - by 762 a.o.m. (12 Cu atoms). The results indicate that $\mathrm{NACH} \mathrm{Cu}$ in both proteins had a higher activity than NACH Fe (Fig. 7).

Since it is known that metals that enter the bloodstream bind temporarily to proteins that are responsible for their transport, distribution in organs and tissues and elimination. Consequently, it can be assumed that the interaction of metals $\mathrm{NP}$ and NACH with albumin is a regulatory mechanism that controls their content in blood and entry to organs $[16,17,26]$. The peculiarities of the influence of metals NP and NACH on the specific protein immunoglobulin G, which has a protective function in the body, were revealed; their binding to the active groups of this protein ( $\mathrm{SH}-$, $\mathrm{COON}-, \mathrm{NH}-$ ) causes its structural changes, as well as changes in the NF metals themselves [18]. The latter can be used in nanopreparations to enhance their bioavailability.

\section{Conclusions}

1. Iron and copper nanoparticles (NP Fe, NP $\mathrm{Cu}$ ) and nanoaquachelates (NACH Fe, $\mathrm{NACH}$ $\mathrm{Cu}$ ) caused structural changes in blood proteins after incubation with human albumin and $\operatorname{IgG}$ under in vitro conditions. At the same time, the proteins increased the solubility of NP, which promoted the release of metal ions, their attachment to the active groups of 
proteins and an increase in the optical density of solutions and the weight of proteins. Metals NP caused more pronounced structural changes in proteins than their NACH.

2. Metal nanoparticles and their nanoaquachelates exhibited selective activity towards proteins, which depended on the size of the nanoparticles, their concentration in the incubation medium and the biological activity of the base metal. NP Cu and NACH Cu interacted more actively with albumin, whereas NP Fe and NACH Fe did so with IgG.

\section{References}

1. Skal'nyj A. V., Rudakov I. A. (2004), Bioelementy v medicine. Moscow : Izdatel'skij dom "Oniks 21 vek»: Mir., $272 \mathrm{p}$.

2. Bondarev L. G. (1984), Mikroelementy - blago i zlo Znanie. Moscow, $142 \mathrm{p}$.

3. Avcin A. P., Zhavoronkov A. A., Rish M. A., Strochkova L. S. (1996), Mikroelementozy cheloveka: etiologiya, klassifikaciya, organopatologiya. Moscow : Medicina, $192 \mathrm{p}$.

4. Chekman I. S. (2009), "Nanochastynky: vlastyvosti ta perspektyvy zastosuvannia", Ukr. biokhimichnyi zhurnal, 81, 1, 122-129.

5. Borisevich V. B., Kaplunenko V. G., Kosinov N. V. et al.; pod redakciej V.B. Borisevicha, V. G. Kaplunenko (2012). Nanomaterialy i nanotekhnologii v veterinarnoj praktike. Kyiv : ВД "Авіцена". 512 p. ISBN978-9662144-40-6.

6. Hulich M. P., Yemchenko N. L., Kaplunenko V. H. et al. (2011), "Perspektyvy zastosuvannia tsytrativ biometaliv, otrymanykh za akvananotekhnolohiieiu yak sposib podolannia defitsytu makro - i mikroelementiv": Tezy dopovidei mizhnarodnoho seminaru "Etyka nanotekhnolohii ta nanobezpeka", 13 zhovtnia 2011 . Kyiv, 46.

7. Kolesnichenko A. V., Timofeev M. V., Protopopova M. V. (2008), «Toksichnost' nanomaterialov - 15 let issledovanij». Rossijskie nanotekhnologii, 3, 3-4.

8. Trakhtenberh I. M., Dmytrukha N. M., KorolenkoT.K., Lahutina O. S. etal.(2017), «Mikroelementy u nanorozmirnomu stani, osoblyvosti biolohichnoi dii, otsinka bezpechnosti». Biulleten XVI chtenyi im. V. V. Podvysotskoho 18-19 maia 2017. Odessa, 1, 348-350.
3. It was determined that the concentrations $0.06 \mathrm{mg} / \mathrm{ml}$ of $\mathrm{NP} \mathrm{Fe}$ and $0.03 \mathrm{mg} / \mathrm{ml}$ of $\mathrm{NP} \mathrm{Cu}, 0.1 \mathrm{mg} / \mathrm{ml}$ of both NACH Fe and $\mathrm{Cu}$ did not cause any changes in the protein structure.

4. The in vitro model «human blood plasma proteins» can be proposed to assess the degree of toxicity and biocompatibility of metals nanopreparates and other nanomaterials, as well as their combination with classical toxicological studies in vivo of their hygienic regulation.

9. Trakhtenberg I. M., Dmytrukha N. M. (2013), "Nanoparticles of metals, methods of definition, spheres of use, physico-chemical and toxic properties". Ukrainian Journal of Occupational Health, 37 (4), 62-74. https://doi.org/10.33573/ ujoh2013.04.062.

10. Chekman I. S., Serdiuk A. M., Kundiiev Yu. I. et al. (2009), "Nanotoksykolohiia: napriamky doslidzhen (ohliad)", Dovkillia ta zdorovia, 1 (48), 3-7.

11. Prodanchuk N. G., Balan M. (2009), «Nanotoxicology: State and perspectives of investigations", Modern problems of toxicology, 3-4, 4-18.

12. Kartel M. T., Tereshchenko P. (2008), "The concept of methodology for identification and toxicological studies of nanomaterials and risk assessment for the human body and the environment in their production and use». Collection of scientific works, Khimiia, fizika i tekhnologhia hjverkhnosti, Naukova dumka, Kyiv, 14, 565-583.

13. Dmytrukha N. M., Lahutyna O. S., Korolenko T. K. et al. (2019), «Zastosuvannia alternatyvvnykh modelei ta metodiv in vitro dlia otsinky bezpeky nanochastynok metaliv". Biuleten XVIII chytan im. V. V. Pidvysotskoho 21-22 travnia 2019, Odesa, 65-67.

14. Lukyanov A. S., Semina T. K., Korolev A. M. (2006), "Prediction of parameters of acute toxicity of chemical compounds by conformation changes in proteins in vitro". Meditsina truda i promyshlennaya ekologiya, 5, 33-40.

15. Prokopenko V. V., Naboka Yu. N., Metelica L. A. et al. (1999), "Chuvstvitel'nost' molekulyarnyh, nadmolekulyarnyh i kletochnyh bioob"ektov k kationam tyazhelyh metallov", Sovremennye problemy toksikologii, 3, 18-21. 
16. Chekunova M. P., Frolova A. D. (1986), «Modern concepts on the biological action of metals", Gigiyena i sanitaria, 12, 18-21.

17. Trachtenberg I. M., Pokrovsky V. O., Dmytrukha N. M. et al. (2009), "Investigations on the effect of heavy metal compounds on human serum immunoglobulin by MALDI-TOF mass spectrometry", Modern problems of toxicology, 1, 37-41.

18. Dmytrukha N. M., Lahutina O. S., Gromovoy T. Yu. (2020), «Investigation of the influence of lead compounds with particles of different dispersity on human blood plasma proteins as an express method for evaluation of their safety", Ukrainian Journal of Occupational Health, 16 (3), 202-209. https://doi. org/10.33573/ujoh2020.03.202.

19. Hardman R. (2006). "A toxicologic review of quantum dots: toxicity depends on physicochemical and environmental factors", Environ. Health Perspect., 114 (2), 165-172. https://doi.org/10.1289/ehp.8284.

20. Zhang J., MaX., Guo Y. et al. (2010), «Sizecontrollable preparation of bovine serum albuminconjugated PbS nanoparticles", Materials Chemistry and Physics, 119 (1), 112-117. https://doi.org/ 10.1016/j.matchemphys.2009.08.027.

21. Kolloidno-himicheskie osnovy nanonauki (2005); pod red. A. P. Shpaka, Z. R. Ul'berg. Kyiv : Akademperiodika, $466 \mathrm{p}$.

22. Patent Ukrainy na korysnu model № 38391. Sposib otrymannia karboksylativ metaliv "Nano- tekhnolohiia otrymannia karboksylativ metaliv", Kosinov M. V., Kaplunenko V. H. / MPK (2006): C07C 51/41, C07F 5/00, C07F 15/00, C07C 53/126 (2008.01), C07C 53/10 (2008.01), A23L 1/00, B82B 3/00. 12.01.2009, biul. № 1/2009.

23. Glen L. Hortin (2006). "The MALDI TOF Mass Spectrometric View of the Plasma Proteome and Peptidome", Clinical Chemistry. 57 (22), 1-11.

24. Porublyova L. V., Rebriev A. V., Gromoviy T. Yu., Minya I.Y. et al. (2009), "MALDI - TOF mass spectrometry in the study of macromolecular biological compounds", Ukrainian Biochemical Journal, 81 (3), 46-57.

25. High Mass Linear Analasis of Intact Proteins on the 4800 MALDI TOF/TOF Ayalyzer. Technical Note. URL: www.appliedbiosystems.com].

26. Lujk A. M., Luk'yanchuk V. D. (1984), Syvorotochnyj al'bumin i biotranspor yadov. Moscow : Medicina, $224 \mathrm{p}$.

27. Kharazian B., Hadipour N. L., Ejtehadi M. R. (2016), «Understanding the nanoparticle-protein corona complexes using computational and experimental methods", J. Biochem Cell Biol., 75, 162-174. https://doi.org/10.1016/j.biocel.2016.02.008.

28. Lundqvist M., Augustsson C., Lilja M. et al (2017), "The nanoparticle protein corona formed in human blood or human blood fractions". PLoS ONE, 12 (4), e0175871. https://doi.org/10.1371/journal. pone.0175871.

\section{ORCID ID of co-authors and their contributions:}

Dmytrukha N. M. (ORCID ID 0000-0001-9161-3889) - analysis of the research results, formulation of the conclusions, preparation of the material for printing;

Lahutina O. S. (ORCID ID 0000-0003-0723-1293) - experimental research, statistic processing of data; Gromovoy T. Yu. (ORCID ID 0000-0003-2157-5033) - measurements and analysis of mass-spectra of proteins on Autoflex mass-spectra of proteins on Autoflex II - (Bruker);

Pylypchuk E. V. (ORCID ID 0000-0001-5467-2839) - measurements and analysis of mass-spectra of proteins, carrying out statistical processing of data.

Information about research funding: the research has been carried out according to the research «Scientific rationale of the principles, methods and indicators of experimental evaluation of the toxicity of nanoparticles and nanomaterials (by the example of heavy metals)», No. of state registration 0113 U001447.

Received: August 11, 2021

Accepted for publication: September 9, 2021

Contact Person: Dmytrukha Natalya, Laboratory of Industrial Toxicology, State Institution «Kundiiev Institute of Occupational Health of the National Academy of Medical Sciences of Ukraine», 75, Saksaganskogo str, Kyiv, 01033. Tel.: + 380442895185 . 